\title{
Variants in MARC1 and HSD17B13 reduce severity of NAFLD in children, perturb phospholipid metabolism, and suppress fibrotic pathways
}

Short title:

MARC1 and HSD17B13 in pediatric NAFLD

Christian A. Hudert ${ }^{1}$, Anna Alisi ${ }^{2}$, Quentin M. Anstee ${ }^{3,4}$, Annalisa Crudele $^{2}$, Laura G. Draijer ${ }^{5}$, EUPNAFLD investigators, Samuel Furse ${ }^{6}$, Jan G. Hengstler ${ }^{7}$, Benjamin Jenkins ${ }^{6}$, Kylie Karnebeek ${ }^{8}$, Deirdre A. Kelly ${ }^{9}$, Bart G. Koot ${ }^{5}$, Albert Koulman ${ }^{6}$, David Meierhofer ${ }^{10}$, Stuart G. Snowden ${ }^{6}$, Indra van Mourik ${ }^{9}$, Anita Vreugdenhil ${ }^{8}$, Susanna Wiegand ${ }^{11}$, Jake P. Mann ${ }^{12}$

\section{Affiliations}

1. Department of Pediatric Gastroenterology, Nephrology and Metabolic Diseases, Charité Universitätsmedizin Berlin, Berlin, Germany

2. Research Unit of Molecular Genetics of Complex Phenotypes, Bambino Gesù Children's Hospital-IRCCS, Rome, Italy

3. Translational and Clinical Research Institute, Faculty of Medical Sciences, Newcastle University, Newcastle upon Tyne, UK

4. Newcastle NIHR Biomedical Research Centre, Newcastle upon Tyne Hospitals NHS Foundation Trust, Newcastle upon Tyne, UK

5. Department of Pediatric Gastroenterology and Nutrition, Amsterdam University Medical Center, Emma Children's Hospital, University of Amsterdam, Netherlands

6. Core Metabolomics and Lipidomics Laboratory, Wellcome Trust-MRC Institute of Metabolic Science, University of Cambridge

7. Systems Toxicology, Leibniz Research Centre for Working Environment and Human Factors at the Technical University Dortmund, Dortmund, Germany

8. Center for Overweight Adolescent and Children's Health Care (COACH), Department of Pediatrics, Maastricht University Medical Center, Maastricht, Netherlands.

9. Liver Unit, Birmingham Women's and Children's Hospital Trust, Birmingham, UK

10. Max Planck Institute for Molecular Genetics, Mass Spectrometry Facility, Berlin, Germany

11. Center for chronically sick children, Charité Universitätsmedizin Berlin, Berlin, Germany

12. Institute of Metabolic Science, University of Cambridge, Cambridge, UK 
medRxiv preprint doi: https://doi.org/10.1101/2020.06.05.20120956; this version posted June 7, 2020. The copyright holder for this preprint (which was not certified by peer review) is the author/funder, who has granted medRxiv a license to display the preprint in perpetuity. It is made available under a CC-BY-NC 4.0 International license.

\title{
Grant support
}

$\mathrm{CAH}, \mathrm{DM}$ and SW are supported by the German Systems Biology Program "LiSyM" (grant no. 31L0057 and 31L0058) sponsored by the German Federal Ministry of Education and Research (BMBF). JPM is supported by a Wellcome Trust fellowship (216329/Z/19/Z), a European Society for Paediatric Research (ESPR) Young Investigator Award, and a Children's Liver Disease Foundation Grant. EU-PNAFLD Registry is supported by a European Association for Study of the Liver (EASL) Registry Grant and by the Newcastle NIHR Biomedical Research Centre/Newcastle University using a database infrastructure developed by the EU EPoS consortium. AA is supported by grant from Italian Ministry of Health (5x1000). SF was supported by funding form BBSRC (BB/M027252/1, original proposal written by AK). BK is supported by grants from Van den Broek Lohman Foundation, Virtutis Opus Foundation and For Wishdom Foundation. QMA in a Newcastle NIHR Biomedical Research Centre investigator and a member of the EU H2020 EPoS (Elucidating Pathways of Steatohepatitis) and EU IMI2 LITMUS (Liver Investigation: Testing Marker Utility in Steatohepatitis) consortia funded under grant agreements 634413 and 777377 respectively. No study sponsors had any role in the study design, or data collection, analysis, and interpretation.

\begin{abstract}
Abbreviations
$\mathrm{Cl}$, confidence intervals; EU-PNAFLD, European Paediatric NAFLD Registry; FA, fatty acids; GSEA, gene set enrichment analysis; HOMA-IR, homeostatic model assessment of insulin resistance; HSD17B13, hydroxysteroid 17 beta-13; MARC1, mitochondrial amidoxime reducing component 1; NAFLD, non-alcoholic fatty liver disease; NASH-CRN, Nonalcoholic Steatohepatitis Clinical Research Network; NES, normalized enrichment score; OR, odds ratio; PC, phosphatidylcholines; PI, phosphatidylinositols PNPLA3, patatin-like phospholipase domain-containing protein 3; TM6SF2, transmembrane 6 superfamily 2;
\end{abstract}

\section{Correspondence:}

Dr. Jake P Mann

Metabolic Research Laboratories

Level 4, Institute of Metabolic Science

Addenbrooke's Hospital

Cambridge, CB2 0QQ

jm2032@cam.ac.uk

Tel: +44 1223336792

Fax: +44 1223330598

\section{Disclosures}

The authors have no conflicts of interest to declare.

\section{Author contributions}


medRxiv preprint doi: https://doi.org/10.1101/2020.06.05.20120956; this version posted June 7,2020 . The copyright holder for this preprint (which was not certified by peer review) is the author/funder, who has granted medRxiv a license to display the preprint in perpetuity. It is made available under a CC-BY-NC 4.0 International license.

Study concept and design (CAH, JPM, BGK, AV, AA); acquisition of data (CAH, AA, AC, LGD, SF, BJ, KK, DAK, BGK, SGS, IVM, AV, JH, DM, JPM); analysis and interpretation of data (CAH, JPM, BGK, AV, AA, DM, QMA); drafting of the manuscript (CAH, JPM); critical revision of the manuscript for important intellectual content (CAH, AA, AC, LGD, SF, BJ, KK, DAK, AK, BGK, SGS, IvM, AV, JH, DM, JPM, QMA); statistical analysis (CAH, SF, SGS, DM, JPM); obtained funding (CAH, BGK, AV, AA, AK, JPM); administrative, technical, or material support (AC, $K K$, BJ); study supervision (CAH, JPM). 
medRxiv preprint doi: https://doi.org/10.1101/2020.06.05.20120956; this version posted June 7, 2020. The copyright holder for this preprint (which was not certified by peer review) is the author/funder, who has granted medRxiv a license to display the preprint in perpetuity. It is made available under a CC-BY-NC 4.0 International license.

\section{Abstract}

Background \& aims: Genome-wide association studies in adults have identified variants in HSD17B13 and MARC1 as protective against NAFLD. It is not known if they are similarly protective in children and, more generally, whether the peri-portal inflammation of pediatric NAFLD and lobular inflammation seen in adults share common genetic influences. Therefore, we aimed to: establish if these variants are associated with NAFLD in children, and to investigate the function of these variants in hepatic metabolism using metabolomics.

Methods: 960 children (590 with NAFLD, 394 with liver histology) were genotyped for rs72613567T>TA in HSD17B13, rs2642438G>A in MARC1. Genotype-histology associations were tested using ordinal regression. Untargeted hepatic proteomics and plasma lipidomics were performed in a subset of samples. In silico tools were used to model the effect of rs2642438G>A (p.Ala165Thr) on MARC1.

Results: rs72613567T>TA in HSD17B13 was associated with lower odds of NAFLD diagnosis (OR $0.7(95 \% \mathrm{Cl} 0.6-0.9)$ and lower grade of portal inflammation $(P<0.001)$ whilst rs2642438G $>\mathrm{A}$ in MARC1 was associated with lower grade of hepatic steatosis $(P=0.02)$. Proteomics found reduced expression of HSD17B13 in carriers of the protective allele, whereas MARC1 levels were not affected by genotype. Both variants showed downregulation of hepatic fibrotic pathways, upregulation of retinol metabolism and perturbation of phospholipid species. Modelling suggests that p.Ala165Thr would disrupt the stability and metal-binding of MARC1.

Conclusions: There are shared genetic mechanisms between pediatric and adult NAFLD, despite their differences in histology. MARC1 and HSD17B13 are involved in phospholipid metabolism and suppress fibrosis in NAFLD.

\section{Keywords}

Single nucleotide variant; steatohepatitis; metabolomics; liver biopsy. 
medRxiv preprint doi: https://doi.org/10.1101/2020.06.05.20120956; this version posted June 7, 2020. The copyright holder for this preprint

(which was not certified by peer review) is the author/funder, who has granted medRxiv a license to display the preprint in perpetuity.

It is made available under a CC-BY-NC 4.0 International license .

\section{Introduction}

Understanding genetic variants associated with human chronic disease phenotypes has yielded insights into multifactorial pathogenesis ${ }^{1}$. This is of particular importance in non-alcoholic fatty liver disease (NAFLD) as it is a common condition with potential to progress to end-stage liver disease and hepatocellular carcinoma ${ }^{2,3}$, yet has no licensed therapies ${ }^{4}$.

Population level genome- and exome-wide association studies have identified several common variants implicated in the severity of NAFLD ${ }^{5}$. p.lle148Met in patatin-like phospholipase domain-containing protein 3 (PNPLA3) is the variant most strongly associated with increased severity of NAFLD ${ }^{6,7}$ and has been well studied, leading to its identification as a lipid dropletbinding protein that influences the recruitment of hydrolysing enzymes ${ }^{8,9}$. p.Glu167Lys in transmembrane 6 superfamily 2 (TM6SF2) is also well-established as a harmful variant that impairs hepatic lipid metabolism and increases risk of all stages of NAFLD ${ }^{10,11}$.

More recently, strong human genetic evidence has identified two protective variants at genomewide significance: rs72613567T >TA in hydroxysteroid 17-beta dehydrogenase $13(\text { HSD17B13 })^{12}$ and p.Ala165Thr in mitochondrial amidoxime reducing component $1(M A R C 1, \text { rs2642438G }>\mathrm{A})^{13}$. $H S D 17 B 13$ has also been implicated in altered lipid metabolism, including recently in regulation of phospholipids ${ }^{14}$ and retinol ${ }^{15}$. However the function of MARC1 in hepatic lipid metabolism is largely unknown, though it clearly has drug detoxifying activity ${ }^{16,17}$ and has been recently implicated in phospholipid metabolism ${ }^{18}$.

Histological validation of genetic variants is challenging due to the comparatively small numbers who undergo liver biopsy for NAFLD. This is even more so the case in pediatric NAFLD, therefore analyses studies are candidate gene studies in relatively small cohorts ${ }^{19,20}$. One genome-wide association study has been conducted in Hispanic boys with biopsy-proven NAFLD, which yielded several suggestive $\operatorname{loci}^{21}$. It is still unclear precisely how closely the genetics of adult and pediatric NAFLD overlap.

Pediatric NAFLD is common $\left(7.6 \%\right.$ in the general population $\left.{ }^{22}\right)$ and shows a predominance of peri-portal inflammation and zone 1 steatosis, particularly in younger male patients ${ }^{23,24}$. Whilst both are positively associated with insulin resistance and other features of the metabolic syndrome $^{25}$, it is not clear whether pediatric peri-portal inflammation in NAFLD is simply a childhood manifestation of 'adult' NASH (with lobular inflammation and ballooning) or a different pathophysiological entity.

Therefore, we sought to address whether the protective variants in HSD17B13 and MARC1 identified at a population-level in adults can be replicated in children with NAFLD, also providing histological validation of p.Ala165Thr in MARC1. In this study we used liver tissue proteomics and plasma lipidomics to gain insight into the impact of these variants on hepatic metabolism in children with NAFLD. 
medRxiv preprint doi: https://doi.org/10.1101/2020.06.05.20120956; this version posted June 7, 2020. The copyright holder for this preprint

(which was not certified by peer review) is the author/funder, who has granted medRxiv a license to display the preprint in perpetuity.

It is made available under a CC-BY-NC 4.0 International license .

\section{Methods}

\section{Participants}

Two groups of participants were included in this cross-sectional study: cases (children with NAFLD) and controls (without NAFLD). A subset of children with NAFLD had undergone liver biopsy for clinical indications. All participants (or their parents) gave written informed consent and were recruited between 2014-2019.

Participants were recruited from six sites. Children with NAFLD were recruited from hepatology \& gastroenterology clinics in Cambridge \& Birmingham (UK) as part of the European Paediatric NAFLD Registry (EU-PNAFLD, Clintrials.gov NCT:04190849) ${ }^{26}$, which was approved by the East Midlands - Nottingham 2 Research Ethics Committee (17/EM/0084).

Obese controls and NAFLD cases were recruited from pediatric obesity clinics at Maastricht University Medical Centre (under ethical approval METC 13-4-130) and Amsterdam University Medical Centre (under ethical approval MEC 2017_306 and MEC 07/141). Obese controls and NAFLD cases were recruited from Bambino Gesu hospital (under ethical approval for EUPNAFLD and local Ethics Review Board, protocol number 1774_OPBG_2019). Children were referred to these clinics due to obesity and were then subsequently investigated for comorbidities, including NAFLD. Children identified to have NAFLD were recruited as cases and those with obesity but no evidence of liver disease (as described below) were included in this study as obese controls.

In addition, NAFLD cases were recruited from the Berlin Cohort $^{27}$ at the pediatric obesity outpatient clinic and pediatric gastroenterology outpatient clinic of Charité (under ethical approval of the local institutional review board EA2/049/14).

Recruitment of controls from the same clinics (and referral populations) as cases aimed to reduce the bias of case-control comparisons. Recruitment from multiple different hospitals aimed to reduce bias associated with a sample from a single hospital population. As an exploratory analysis, we utilised data from the maximum number of available participants therefore no formal sample size calculation was performed.

\section{Inclusion and exclusion criteria}

All participants were 5-18 years old at the time of inclusion.

Cases ( $n=590$ ): All cases were identified with abnormal biochemistry (alanine aminotransferase $(\mathrm{ALT})>44 \mathrm{U} / \mathrm{l}$ for girls or $>50 \mathrm{U} / \mathrm{l}$ for boys and/or aspartate aminotransferase (AST) $>50 \mathrm{U} / \mathrm{l}^{28}$ ) and/or radiological evidence of steatosis (ultrasound, magnetic resonance imaging, or controlled attenuation parameter $\geq 240)$. Imaging was available for 571 patients $(97 \%)$. Liver biopsy with histological characterization of NAFLD was available for $394(67 \%)$ patients.

Controls ( $n=412$ ): NAFLD was excluded by absence of hepatic steatosis upon radiologic examination (ultrasound, magnetic resonance imaging, or controlled attenuation parameter $<240)$, or where not available $(n=177,43 \%)$ with normal aminotransferases. 
medRxiv preprint doi: https://doi.org/10.1101/2020.06.05.20120956; this version posted June 7, 2020. The copyright holder for this preprint

(which was not certified by peer review) is the author/funder, who has granted medRxiv a license to display the preprint in perpetuity.

It is made available under a CC-BY-NC 4.0 International license .

Exclusion criteria were: age $<5$ or $>18$ years, any other liver disease (assessment for secondary causes including: alpha-1-antitrypsin deficiency, celiac disease, autoimmune hepatitis, viral hepatitis A, B and C, active cytomegalovirus or Epstein-Barr virus infection, thyroid disorders, and Wilson's disease), severe underlying chronic disease (e.g., cardiopulmonary or autoimmune disease), alcohol consumption $>20 \mathrm{~g}$ of alcohol per day, and pregnancy.

Children with incomplete data, inadequate genotyping quality or unclear genotyping call were also excluded. Thirty-six patients initially recruited were excluded, 32 were under 5 or over 18 years old, 2 with unclear diagnosis, and 4 without adequate data.

\section{Clinical and laboratory investigations}

In all cases and obese controls included in the study, anthropometric measures (height, weight) were taken, laboratory analysis including a hepatic panel and complete blood count was performed, and fasted state metabolic parameters were assessed by using standardized procedures. The homeostatic model assessment of insulin resistance (HOMA-IR) was derived using fasting insulin $(\mu \mathrm{U} / \mathrm{L}) \times$ fasting glucose $(\mathrm{nmol} / \mathrm{L}) / 22.5$. Obesity was defined as body mass index (BMI) z-score $>2$.

\section{Genotyping}

DNA was extracted from whole blood (using Qiagen DNeasy kit \#69504). Participants were genotyped by quantitative polymerase chain reaction using TaqMan assays (ThermoFisher \#4351379): rs738409C $>\mathrm{G}$ in PNPLA3, rs58542926C $>\mathrm{T}$ in transmembrane 6 superfamily 2 (TM6SF2), rs2642438G >A in MARC1, and rs72613567T>TA in HSD17B13 (using the custom sequence from Pirola et al. ${ }^{29}$ ). These variants were selected due to their evidence as genomewide risk factors for NAFLD and cirrhosis in adults $6,7,10,12,13,30,31$. Data on variants in HSD17B13 and MARC1 were available for 960 participants whilst data on PNPLA3 variants were available for 490 participants and data on TM6SF2 variants were available for 489 participants.

All variants were within Hardy-Weinberg equilibrium in the control groups using Chi-squared test: rs58542926C $>$ T in TM6SF2, $P=0.08$; rs2642438G $>$ A in MARC1, $P=0.21$; and rs72613567T $>$ TA in $H S D 17 B 13, P=0.56$, rs738409C $>G$ in PNPLA3, $P=0.53$.

\section{Liver biopsies}

Liver biopsies were evaluated and scored by experienced pathologists of the respective centers. Staging and grading was performed according to the histological scoring system for non-alcoholic fatty liver disease by the Nonalcoholic Steatohepatitis Clinical Research Network (NASH-CRN) ${ }^{32}$. Briefly, grading included the scoring of steatosis $(0=<5 \% ; 1=5-33 \% ; 2=34-66 \% ; 3=\geq 67 \%$ ), lobular inflammation $(0=0 / 200 x$ field; $1=<2$ foci $/ 200 x$ field; $2=2-4$ foci $/ 200 x$ field; $3=>4$ foci $/ 200 x$ field), and hepatocellular ballooning ( $0=$ none; $1=\mathrm{few} ; 2=$ many/prominent). Portal inflammation was evaluated according to Brunt et al. ${ }^{33}(0=$ none; $1=$ mild; $2=$ moderate to severe). Staging of fibrosis was performed using NASH-CRN criteria $(0=$ no fibrosis; $1=$ zone 3 perisinusoidal only or portal/periportal without bridging only; $2=$ zone 3 perisinusoidal + portal/periportal; $3=$ bridging fibrosis; $4=$ cirrhosis). 
medRxiv preprint doi: https://doi.org/10.1101/2020.06.05.20120956; this version posted June 7, 2020. The copyright holder for this preprint

(which was not certified by peer review) is the author/funder, who has granted medRxiv a license to display the preprint in perpetuity. It is made available under a CC-BY-NC 4.0 International license .

\section{Hepatic proteomic analysis}

Hepatic tissue proteomics was performed in a subset of 70 patients, as previously described ${ }^{27}$. Liver biopsy specimens were extracted under denaturing conditions and digested by trypsin for subsequent analysis by mass spectrometry ${ }^{34}$. The software tools MaxQuant ${ }^{35}$ and gene set enrichment analysis (GSEA) ${ }^{36}$ were used for peptide identification and pathway analyses, respectively (see Supplementary Methods for details).

\section{In silico analysis of MARC1 p.Ala165Thr}

Our hepatic proteomics data suggested that this MARC1 variant did not alter expression of MARC1 protein, unlike for the studied HSD17B13 variant. Therefore, to further provide some insight into the impact of rs2642438G $>$ A (p.Ala165Thr) in MARC1 we used a range of bioinformatics tools to perform an in silico analysis of the variant. UniProt ${ }^{37}$ was searched for isoforms of MARC1 in other species and sequences aligned. Four tools were chosen to be used for prediction of the impact of the missense variant based on recommendations of accuracy from the range of tools available ${ }^{38,39}:$ SNPs\&GO ${ }^{40}$, PANTHER $^{41}$, Align-GVGD ${ }^{42}$, and MutPred2 ${ }^{43}$. For a structural analysis, we used the available crystal structure of $M A R C 1^{44}$ and three tools for calculating the effect of p.Ala165Thr on overall protein stability: I-Mutant3.0 ${ }^{45}$, DUET ${ }^{46}$, and CUPSAT ${ }^{47}$. Data on in silico saturation mutagenesis of MARC1 were available from EVmutation. An annotated protein model was generated using UCSF Chimera ${ }^{48}$.

\section{Plasma lipidomics analysis}

Plasma lipidomics was performed in a subset of 129 children with NAFLD who had undergone liver biopsy. The methods have been described in detail elsewhere ${ }^{49}$, but in brief, lipids, triglycerides and sterols were extracted together from fasting plasma using a high throughput technique followed by direct infusion mass spectrometry (DI-MS) ${ }^{50}$.

Data acquisition--Samples were infused into an Exactive Orbitrap (Thermo, Hemel Hampstead, UK), using a Triversa Nanomate (Advion, Ithaca, NY, USA). Positive ionisation mode was achieved at a $1.2 \mathrm{kV}$. The Exactive started acquiring data $20 \mathrm{~s}$ after sample aspiration began. The Exactive acquired data with a scan rate of $1 \mathrm{~Hz}$ (resulting in a mass resolution of 65,000 full width at half-maximum (fwhm) at $400 \mathrm{~m} / \mathrm{z}$ ). After $72 \mathrm{~s}$ of acquisition in positive mode the Nanomate and the Exactive switched over to negative mode, decreasing the voltage to $-1.5 \mathrm{kV}$. The spray was maintained for another $66 \mathrm{~s}$, after which Collision-Induced Dissociation commenced, with a mass window of 50-1000 Da, and was stopped after another $66 \mathrm{~s}$. The sample plate was kept at $10^{\circ} \mathrm{C}$ throughout the data acquisition.

Data processing--Raw high-resolution mass-spectrometry data were converted to mzXML files and then processed using XCMS (www.bioconductor.org) and Peakpicker v 2.0 (an in-house R script ${ }^{51}$ ). Lists of known species (by $\mathrm{m} / \mathrm{z}$ ) were used for both positive ion and negative ion mode ( 8.5k species). Identification of species was compared against validated lists of species used by this group ${ }^{51-55}$. Variables whose mass deviated by more than $9 \mathrm{ppm}$ from the expected value, had a signal-to-noise ratio of $<3$ and had signals for fewer than $50 \%$ of samples were discarded. 
medRxiv preprint doi: https://doi.org/10.1101/2020.06.05.20120956; this version posted June 7, 2020. The copyright holder for this preprint

(which was not certified by peer review) is the author/funder, who has granted medRxiv a license to display the preprint in perpetuity.

It is made available under a CC-BY-NC 4.0 International license .

Signals were then divided by the sum of signals for that sample and expressed per mille $(\%)$. Zero values were interpreted as not measured.

\section{Statistical analyses}

Testing for normal distribution was performed for all variables using the Shapiro-Wilk method. Frequencies and percentages are presented for clinical (categorial) and histological (ordinal) characteristics. Medians and quartiles of continuous anthropometric and laboratory parameters were calculated for the total study population as well as for subgroups (stratification for the presence of NAFLD, variant genotype within cases, patients with proteomic or lipidomic profiles). To evaluate differences in distribution between cases and controls as well as within genotypes of variants we used Kruskal-Wallis test for continuous nonparametric values (age, BMI-Z score). Chi-squared tests were applied to categorical and ordinal variables (gender and presence of obesity). For all continuous laboratory values, linear regression models with correction for age and gender were used.

Hardy-Weinberg equilibrium was tested using a chi-squared test with one degree of freedom for all genetic variants. Case-control studies between the different genotypes were analyzed using chi-squared tests and logistic regression models for distinct genetic modes of inheritance: no particular genetic model (genotypes), additive (trend), dominant, recessive or multiplicative (alleles). Additive (or linear mixed) genetic models were used in the identification of these variants as significant risk loci ${ }^{12,13}$ and therefore we have primarily used the additive model in all analyses. Effects of variants were calculated using Wald tests, odds ratios (OR) and 95\% confidence intervals $(95 \% \mathrm{Cls})$. False discovery rate-adjusted Q-values were calculated using the BenjaminiHochberg procedure to adjust for multiple testing. Associations between genotypes and histological features were tested using univariate ordinal regression or multivariate ordinal regression models with correction for age, sex, BMI z-score and HOMA-IR. Dichotomous histological associations were tested by binary logistic regression with correction for age and sex. OR and $95 \% \mathrm{Cls}$ were calculated. Genotype was coded by number of 'protective' alleles: HSD17B13 rs72613567 T/T=0, T/TA=1, TA/TA=2; and MARC1 rs2642438 G/G=0, G/A=1, A/A=2. Proteomic studies: see Supplementary Methods.

Lipidomic studies: relative abundances for each lipid were logarithmically transformed and standardised (to mean $=0$, standard deviation $=1$ ). Missing values were ignored and no imputation was used. Linear regression analyses adjusted for sex and age were run to test for associations between lipid species and genotype. The beta regression coefficients were then plotted against length of carbon chain and number of double-bonds. Due to high correlation between lipid species, the critical $p$-value for significance was defined by $0.05 / \sqrt{ } n$, where $n$ is the number of identified species from each analysis method.

Statistical analysis was performed in SPSS (IBM Corp. Released 2017. IBM SPSS Statistics for Windows, Version 25.0. Armonk, NY: IBM Corp). Further regression analysis was performed in Stata v16.1 (StataCorp) and random forest analysis was performed using R $3.6 .1^{56}$, in addition, graphs were produced in GraphPad v8.0 for Mac, GraphPad Software, La Jolla California, USA. 
medRxiv preprint doi: https://doi.org/10.1101/2020.06.05.20120956; this version posted June 7, 2020. The copyright holder for this preprint (which was not certified by peer review) is the author/funder, who has granted medRxiv a license to display the preprint in perpetuity. It is made available under a CC-BY-NC 4.0 International license.

\section{Results}

\section{Characteristics of the study population}

One thousand two children (590 with NAFLD and 412 controls) were included in the study. Children with NAFLD were older, more likely to be male, more insulin resistant and dyslipidemic despite being less obese (Table 1). They exhibited higher liver transaminases, with median ALT being elevated more than 2 times as compared to the control group.

\section{Association between variants in MARC1, HSD17B13, TM6SF2, PNPLA3 and NAFLD}

First, we sought to determine whether these variants were associated with diagnosis of NAFLD in children (Figure 1). rs $738409 \mathrm{C}>\mathrm{G}$ in PNPLA3 was positively associated with diagnosis of NAFLD (odds ratio (OR) 1.79 (95\% Cl 1.26-2.53). rs72613567T>TA in HSD17B13 was protective against diagnosis of NAFLD (OR $0.70(95 \% \mathrm{Cl} 0.56-0.87)$ ) though no association with diagnosis of NAFLD was observed with rs2642438G $>A$ in MARC1 or rs58542926C $>T$ in TM6SF2 (Supplementary Table 1).

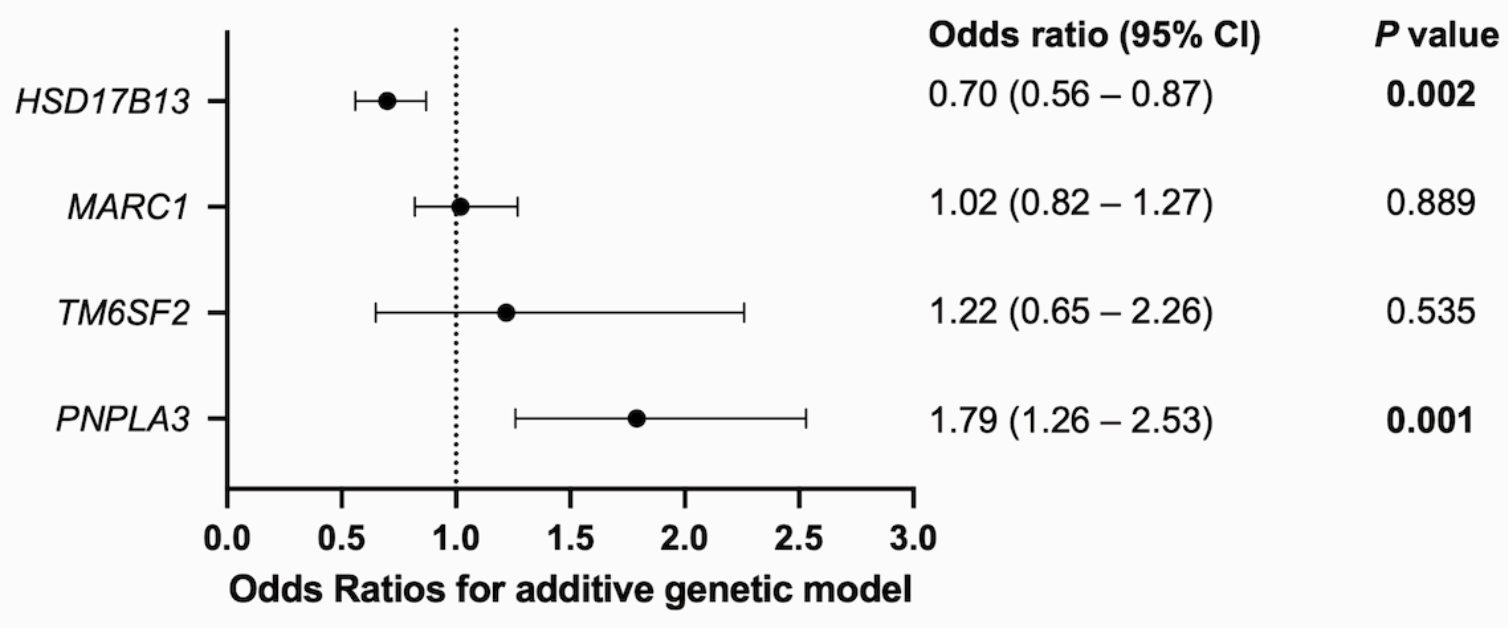

Figure 1. Odds ratios for the presence of NAFLD using an additive genetic model. Data from 590 children with NAFLD (cases) and 370 controls. $P$-values were calculated using logistic regression with correction for age and sex. 'PNPLA3' refers to rs738409C $>\mathrm{G}$, 'MARC1' refers to rs2642438G >A, and 'HSD17B13' refers to rs72613567T>TA and 'TM6SF2' refers to rs58542926C $>T$.

In children with NAFLD, rs72613567T>TA in HSD17B13 and rs2642438G>A in MARC1 were not associated with any anthropometric or biochemical traits (Supplementary Tables $2 \& 3$ ). 
medRxiv preprint doi: https://doi.org/10.1101/2020.06.05.20120956; this version posted June 7, 2020. The copyright holder for this preprint (which was not certified by peer review) is the author/funder, who has granted medRxiv a license to display the preprint in perpetuity. It is made available under a CC-BY-NC 4.0 International license .

\section{Effect of single nucleotide variants on histological severity of NAFLD}

Of those with NAFLD, 394 (67\%) had undergone liver biopsy (Table 2 \& Supplementary Table 4). Participants displayed the whole spectrum of NAFLD from simple steatosis to NASH-associated cirrhosis. $70 \%$ had evidence of peri-portal inflammation and $13 \%$ had advanced fibrosis (stage 3-4).

Consistent with its well-established harmful effect on NAFLD in adults, rs738409C $>\mathrm{G}$ in $P N P L A 3$ was associated with a higher grade of steatosis $\left(P=3.2 \times 10^{-5}\right)$, lobular inflammation $(P=0.02$, and fibrosis stage $(P=0.02)$ on multivariable ordinal regression adjusted for age, sex, BMI, and HOMA-IR (Figure 2 \& Supplementary Table 5).

Whereas, variants in $H S D 17 B 13$ and in MARC1 were associated with less advanced histological features (Figure $2 \&$ Supplementary Table 5). rs72613567T>TA in HSD17B13 was strongly associated with lower grade of portal inflammation $\left(P=1.5 \times 10^{-4}\right)$ and rs2642438G $>$ A in MARC1 was associated with lower grade of steatosis $(P=0.02)$. Both protective variants showed a trend towards a lower fibrosis stage but no significant association on ordinal regression analysis.

Similar results were observed using a dichotomous analysis: PNPLA3 increased odds for the development of both moderate fibrosis (OR 1.33 (95\% Cl $1.00-1.78)$ ) and advanced fibrosis (OR $1.96(95 \% \mathrm{Cl} 1.29$ - 3.00)), while HSD17B13 and MARC1 were associated with lower odds for moderate fibrosis (OR $0.66(95 \% \mathrm{Cl} 0.45-0.99)$ or advanced fibrosis (OR $0.53(95 \% \mathrm{Cl} 0.30$ 0.94)) respectively (Supplementary Figure $1 \&$ Supplementary Table 6).

There was no association of $\mathrm{rs} 58542926 \mathrm{C}>\mathrm{T}$ in TM6SF2 with any histological trait (Supplementary Tables $5 \& 6$ ). 
medRxiv preprint doi: https://doi.org/10.1101/2020.06.05.20120956; this version posted June 7, 2020. The copyright holder for this preprint (which was not certified by peer review) is the author/funder, who has granted medRxiv a license to display the preprint in perpetuity.

A

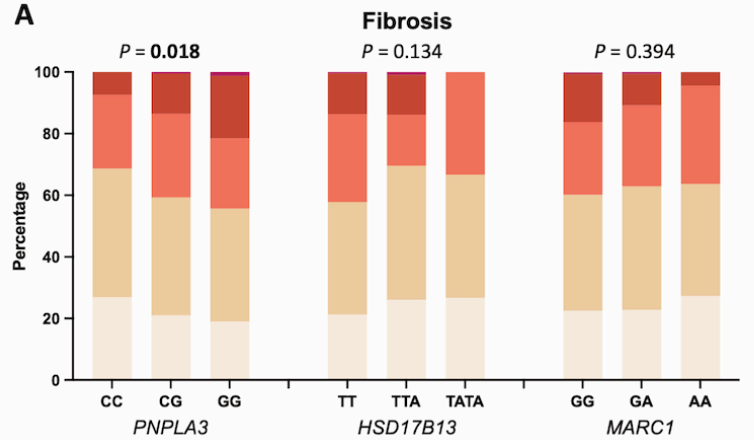

C

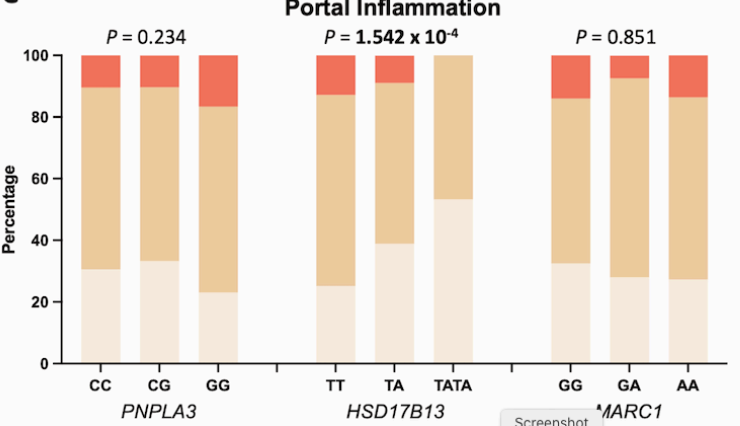

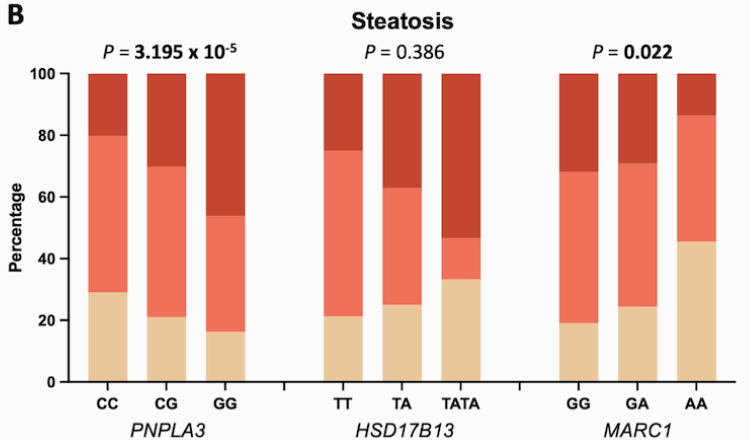

D

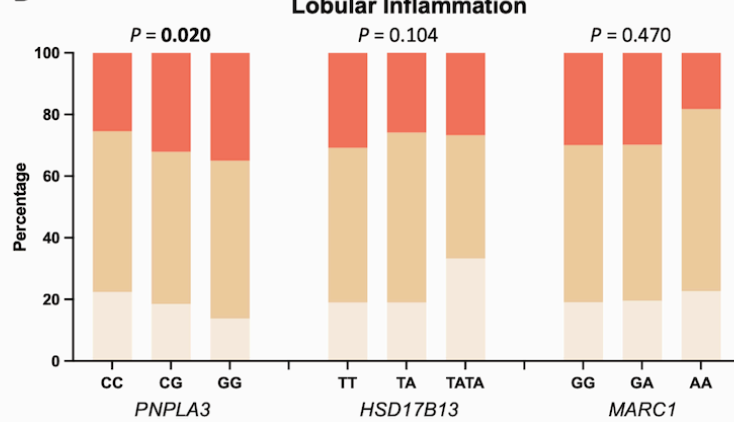

Figure 2. Effect of SNV on histological severity of NAFLD in children. Data from 394 children genotyped for rs738409C>G (PNPLA3), rs72613567T>TA (HSD17B13) and rs2642438G>A (MARC1). Multivariate ordinal regression analysis with correction for age, sex, BMI z-score and HOMA-IR was performed for the association of the respective genotypes with (A) fibrosis stage [0-4], (B) steatosis grade [1-3], (C) portal inflammation [0-2], and (D) lobular inflammation [0-2].

\section{Liver proteomics implicates variants in HSD17B13 and MARC1 in fibrosis and lipid metabolism}

In order to understand the effect of these variants on liver function, we performed proteomics on liver biopsy samples from 70 children with NAFLD, who were representative of the overall NAFLD group (Supplementary Table 7). rs72613567T>TA was associated with lower abundance of HSD17B13 liver protein (Figure 3A\&B \& Supplementary Table 8). Whereas hepatic levels of MARC1 protein did not appear to be affected by rs2642438G>A genotype (Figure 3C \& Supplementary Table 8).

Gene set enrichment analysis (GSEA) for rs72613567T>TA in HSD17B13 genotype implicated changes in multiple gene sets, including a strong upregulation of ribosomal activity (e.g. KEGG_RIBOSOME, normalized enrichment score $(N E S)=3.0 ; Q=0$ ) and nonsense-mediated decay (e.g. REACTOME_NONSENSE_MEDIATED_DECAY, NES $=2.74 ; Q=0$ ), consistent with degradation of mutant HSD17B13 (Supplementary Table 9). When the enriched gene sets were mapped for similarity (Figure 3D) several trends could be observed: there was a strong signature of downregulation of pathways associated with immune response (e.g. HALLMARK_INTERFERON_GAMMA_RESPONSE, NES $=-2.4, Q=0)$. Multiple metabolic 
medRxiv preprint doi: https://doi.org/10.1101/2020.06.05.20120956; this version posted June 7,2020 . The copyright holder for this preprint (which was not certified by peer review) is the author/funder, who has granted medRxiv a license to display the preprint in perpetuity. It is made available under a CC-BY-NC 4.0 International license.

pathways appeared to be perturbed including upregulation of fatty acid processing (e.g. KEGG_FATTY_ACID_METABOLISM, NES $=2.82 ; Q=0)$. There was also downregulation of pathways and proteins associated with extracellular matrix formation (e.g. GO_COLLAGEN_CONTAINING_EXTRACELLULAR_MATRIX, NES $=-1.9 ; Q=0.047$ ).

GSEA for rs2642438G>A in MARC1 similarly found a strong signature for downregulation of extracellular matrix and collagen-related pathways (e.g. GO_COLLAGEN_TRIMER, NES: -2.46, $Q=0.010$ and GO_EXTRACELLULAR_MATRIX_STRUCTURAL_CONSTITUENT, NES = -2.35; $Q=0.018$ ) as well as gene sets related to the innate immune response (Figure $3 E$ \& Supplementary Table 9). There was a strong enrichment in gene sets associated with mitochondrial metabolism, drug detoxification, sphingolipid metabolism, and redox reactions (e.g. GO_SPHINGOLIPID_METABOLIC_PROCESS, NES $=2.15, \quad Q=0.05$ and GO_OXIDOREDUCTASE_ACTIVITY, NES $=1.9, Q=0.16$ ).

GSEA for both protective variants demonstrated an upregulation of retinol metabolism (NES = 2.45; $Q=4.5 \times 10^{-5}$ for $H S D 17 B 13$ and NES = 2.14; $Q=0.03$ for MARC1). 
medRxiv preprint doi: https://doi.org/10.1101/2020.06.05.20120956; this version posted June 7, 2020. The copyright holder for this preprint (which was not certified by peer review) is the author/funder, who has granted medRxiv a license to display the preprint in perpetuity.

It is made available under a CC-BY-NC 4.0 International license .

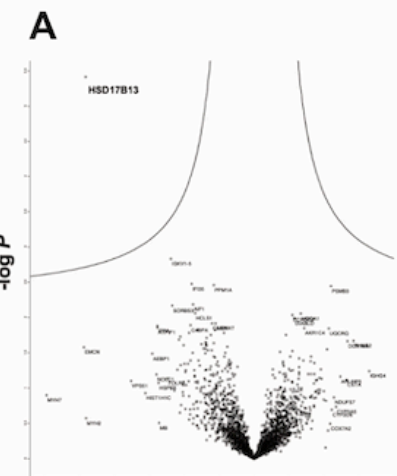

log2 TATA vs. T/T
B

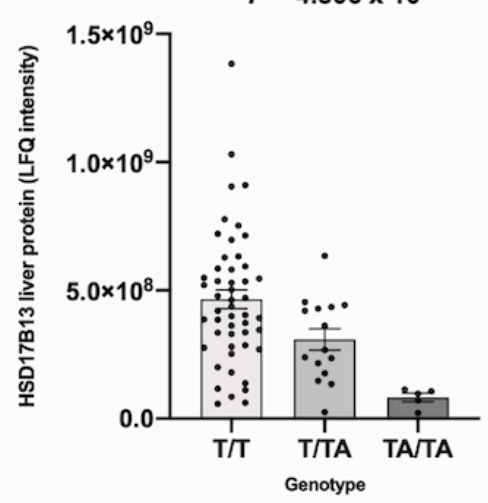

C

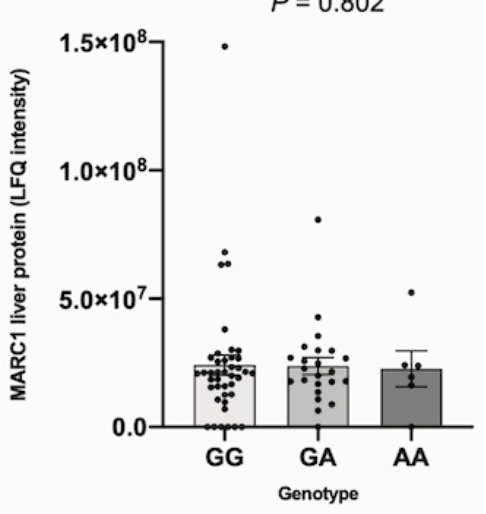

D

HSD17B13

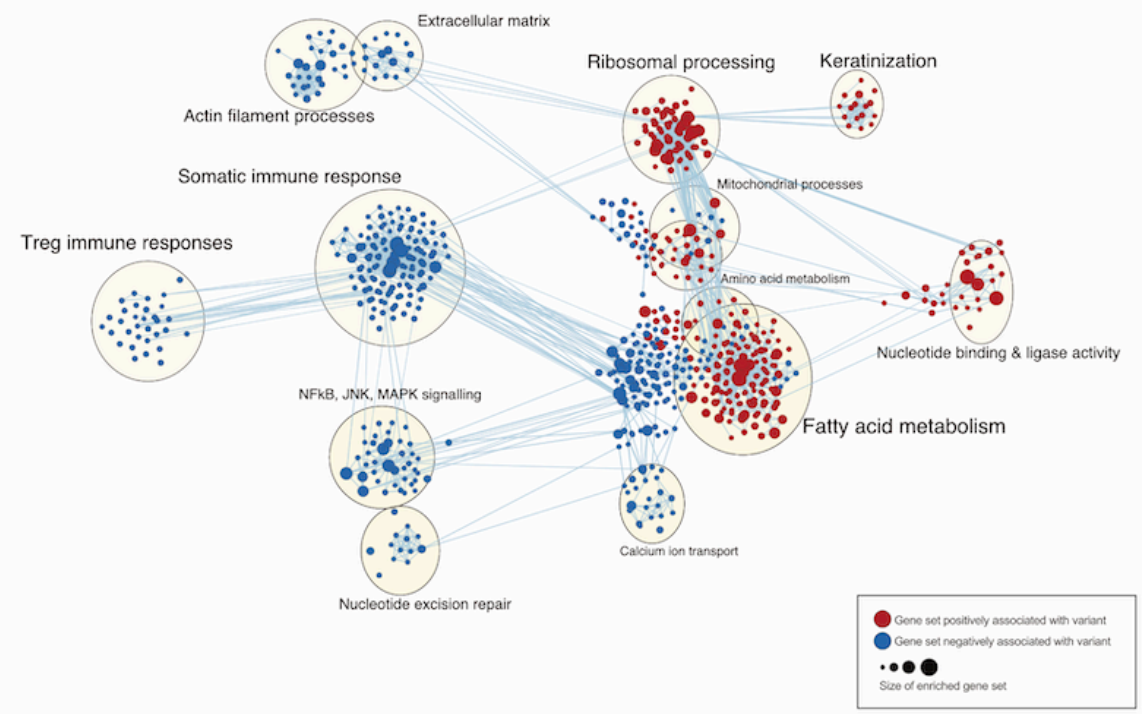

$\mathrm{E}$

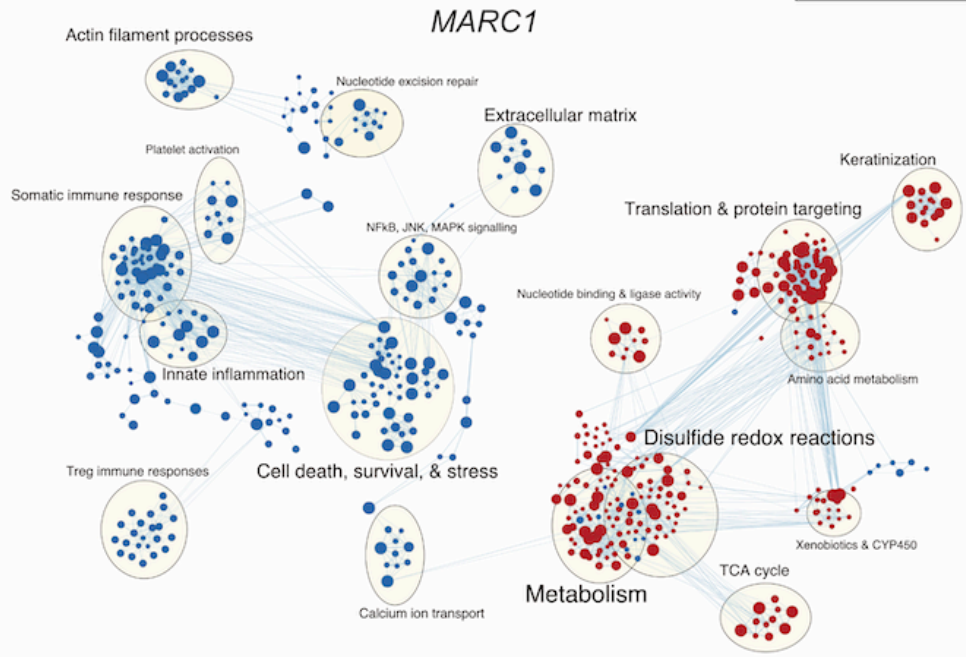


medRxiv preprint doi: https://doi.org/10.1101/2020.06.05.20120956; this version posted June 7, 2020. The copyright holder for this preprint (which was not certified by peer review) is the author/funder, who has granted medRxiv a license to display the preprint in perpetuity. It is made available under a CC-BY-NC 4.0 International license .

Figure 3. Liver proteomics in children with NAFLD, stratified by rs72613567T>TA in HSD17B13 \& rs2642438G $>A$ in MARC1 variants. (A) A volcano plot of $\log _{2}$ abundance ratios against the $\log _{10}$ ( $p$-value) of the proteome for the HSD17B13 TA/TA vs. T/T genotype. (B) Absolute abundance levels (LFQ intensity) stratified by genotype for HSD17B13 liver protein and (C) MARC1 liver protein. Reported $P$ values were calculated using Kruskal-Wallis test. (D) Enrichment map of up- (red) or downregulated (blue) pathways for HSD17B13 genotype as discovered by gene set enrichment analysis using an additive genetic model. (E) Enrichment map of up- (red) or downregulated (blue) pathways for MARC1 genotype as discovered by gene set enrichment analysis using an additive genetic model.

\section{In silico analysis of MARC1 p.Ala165Thr indicates loss of stability} rs72613567T>TA in HSD17B13 falls at a splice-site and our proteomics data suggests this results in reduced expression through nonsense mediated decay. However, the effect of rs2642438G $>A$ (coding for p.Ala165Thr) on MARC1 is less clear, as our proteomics results did not show any change in expression of MARC1 with genotype.

MARC1 position 165 lies within the cytoplasm (with positions 2-20 within the mitochondrial matrix) and is part of the MOSC (MOCO sulfurase C-terminal) domain. The crystalline structure of MARC1 has been resolved to $1.78 \AA$ and shows that alanine- 165 forms part of an alpha-helix on the external surface of the enzyme (Figure 4A\&B). Alanine-165 is highly conserved across mammals (Figure 4C), though the Zebrafish isoform of MARC1 has a different structure in this region. Using in silico saturation mutagenesis, we observed that Alanine-165 is considered to have a substantial beneficial effect on the protein, compared to other predicted missense variants in MARC1 (Figure 4D). Whilst position 165 is not within any of the predicted active sites of $M A R C 1$, two prediction tools classified the p.Ala165Thr variant as disease causing, suggesting that it would cause loss of the alpha-helix and alter the metal binding ability of MARC1 (Supplementary Table 10). Consistent with this, the p.Ala165Thr variant is also predicted to affect the overall stability of the protein. 
medRxiv preprint doi: https://doi.org/10.1101/2020.06.05.20120956; this version posted June 7, 2020. The copyright holder for this preprint (which was not certified by peer review) is the author/funder, who has granted medRxiv a license to display the preprint in perpetuity. It is made available under a CC-BY-NC 4.0 International license .

A

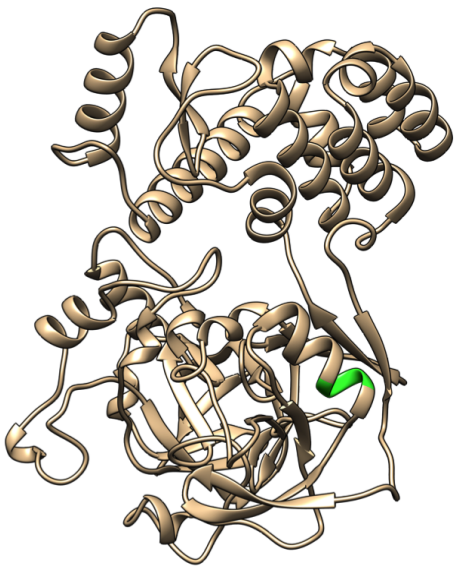

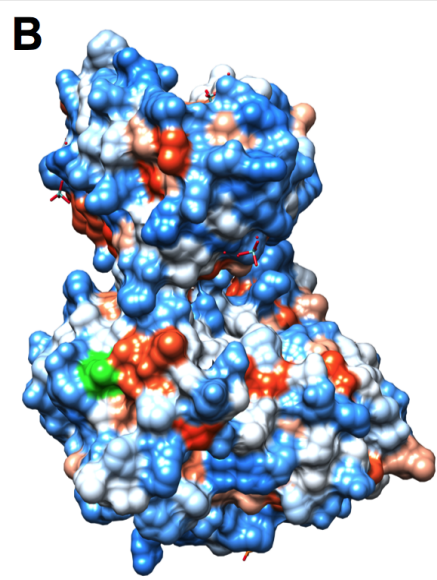

165
C

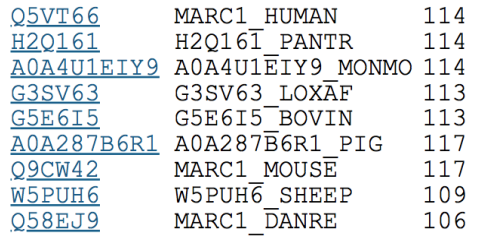

LISLTCDGDTLTLSAAYTKDLLLPIKTPTTNAVHKCRVHGLEIEGRDCGEATAQWITSFI LISLTCDGDTLTLSAAYTKDLLLPIKTPTTNAVHKCRVHSLEIEGRDCGEAAAOWITSFT LISLTCEGDTLTLSAAYTKDLRLPIKTPTTNAVHKCRVOGLEIEGRDCGEAAAHWITNFT LISLTCDGDSLTLSAAYTKDLLLPIRTPTTNAVRQCRVHGLEIEGRDCGDAAAEWITSFI LISLTCEGDTLTLSAAYTKDLQLPVKT PTTNVVHRCRVHGLEIEGRDCGEAAAQWITNFI LISPTCEGDTLTLSAAYTEDLQLPIKAPTTNAVHNCRVQGLQIQGRDCGEAAAQWITSFI LISLTCEDDTLTLSAAYTKDLLLPITPPATNPLLQCRVHGLEIQGRDCGEDAAQWVSSFI LISLTCEGDLLTLSAAYTKDLOLPVKT PTTNVVHKCRVHGLEIEGRDCGEAAAOWITNFI LVSLTCEGGHVSLNGPQMEELKFPLNNS-SDLVVDCRVFSVDVQGRDCGDKVSEWLTRFI

\section{D}

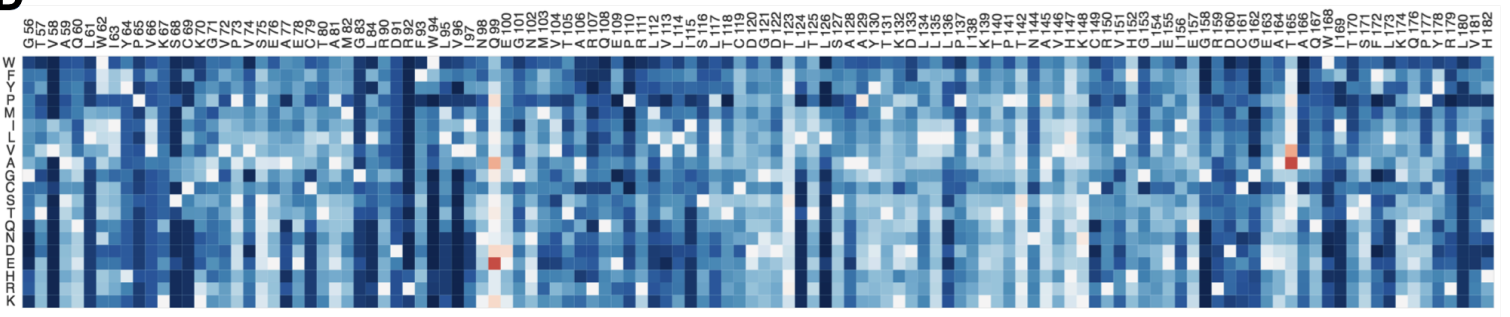

Figure 4. In silico prediction of the effects of p.Ala165Thr on MARC1. Alanine-165 (green) forms part of an alpha helix (A) and forms part of the external surface of MARC1 (B). This position is highly conserved in mammals using alignment of protein isoforms $(C)$. Saturation mutagenesis results from EVmutation predicts an increase in protein function (red) when substituting alanine for threonine at position 165 (D).

\section{Plasma lipidomics shows variants in HSD17B13 and MARC1 perturb phospholipid metabolism}

Given that proteomics data implicates these protective variants in (glycerophospho)-lipid metabolism, we performed untargeted plasma lipidomics in 129 children with biopsy-defined NAFLD and who were representative of the overall NAFLD group (Supplementary Table 11). We 
medRxiv preprint doi: https://doi.org/10.1101/2020.06.05.20120956; this version posted June 7,2020 . The copyright holder for this preprint (which was not certified by peer review) is the author/funder, who has granted medRxiv a license to display the preprint in perpetuity. It is made available under a CC-BY-NC 4.0 International license .

tested for associations between variant genotypes and lipid species using linear regression, adjusted for age and sex.

rs72613567T > TA in HSD17B13 was associated with changes in phosphatidylcholines (PC) and fatty acids (FA) derived from phospholipids (Figure $5 A-C$ ). This variant showed a trend towards positive associations with unsaturated FA and negative associations with polyunsaturated FA (Figure $5 \mathrm{C}$ ). The opposite trend was observed with phosphatidylethanolamines (Supplementary Figure 2). rs2642438G>A in MARC1 was negatively associated with PC (Figure 5D), again unaffected by chain length (Figure $5 E$ \& Supplementary Figure 3 ), and with phosphatidylinositols (PI, Figure 5F).

The harmful variant rs $738409 \mathrm{C}>\mathrm{G}$ in PNPLA3 was also associated with changes in $\mathrm{PC}$, though the direction was influenced by the number of double bonds and carbon chain length (Supplementary Figure 4).

These associations did not appear to be reflective of changes in fibrosis stage, steatosis, or inflammatory activity (Supplementary Figure 5). Fibrosis stage was negatively associated with PC chain length and number of double bonds, whilst NAFLD Activity Score was negatively associated with triglyceride chain length. 
medRxiv preprint doi: https://doi.org/10.1101/2020.06.05.20120956; this version posted June 7, 2020. The copyright holder for this preprint (which was not certified by peer review) is the author/funder, who has granted medRxiv a license to display the preprint in perpetuity. It is made available under a CC-BY-NC 4.0 International license.
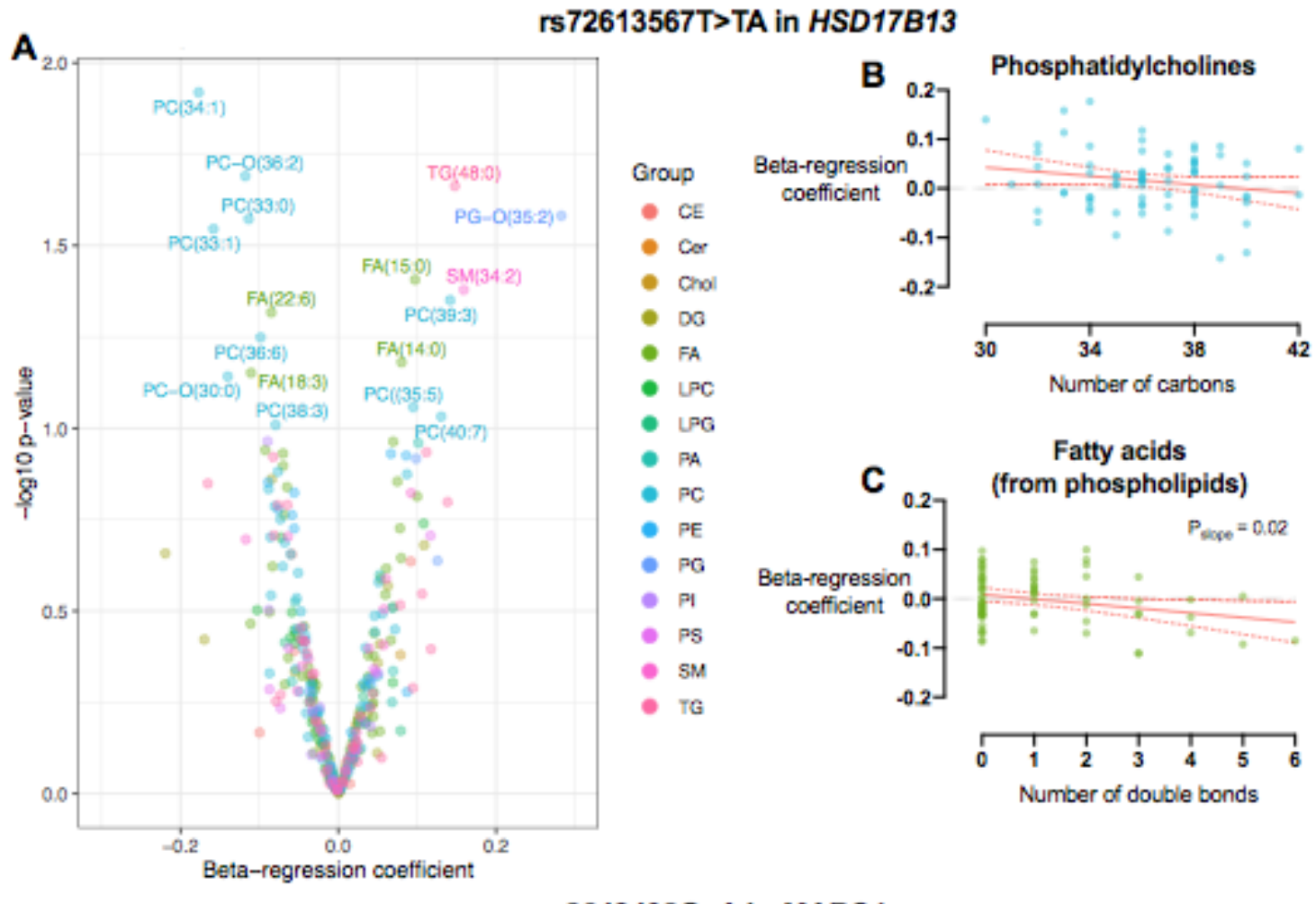

D

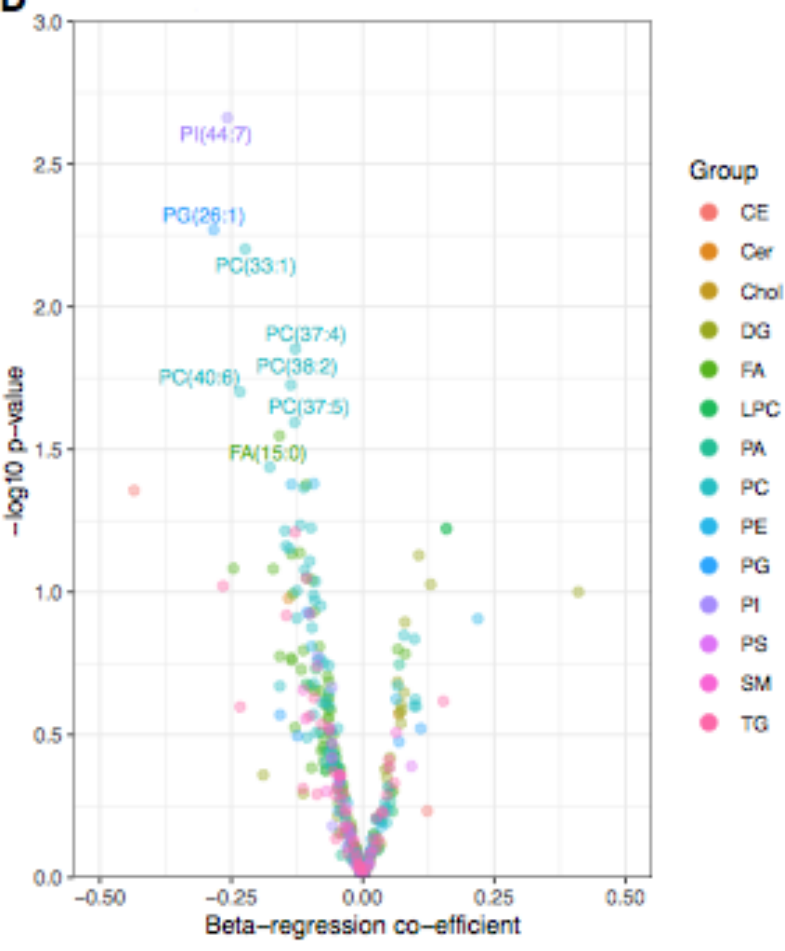

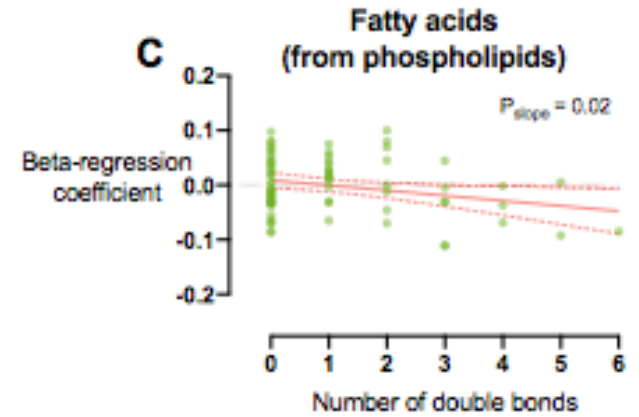

Number of double bonds
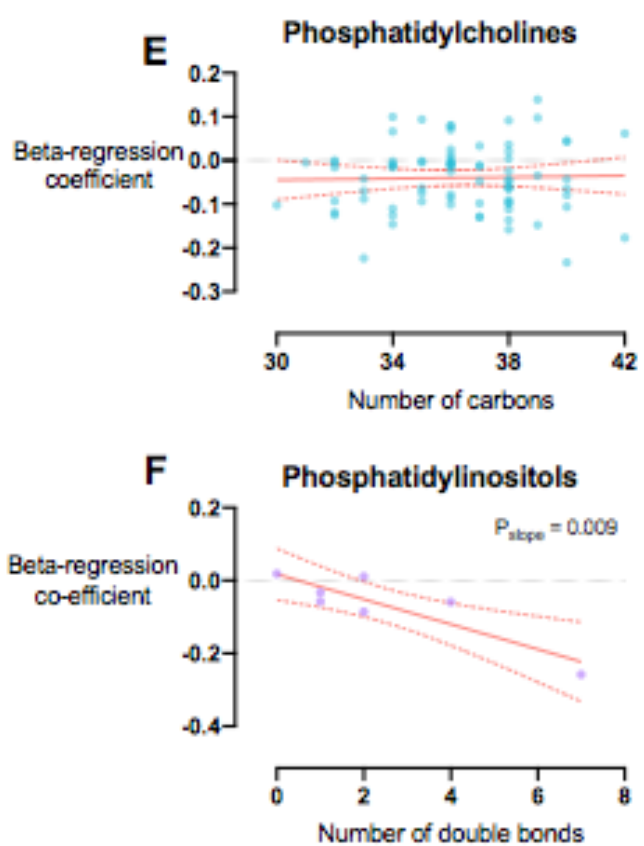

Figure 5. Plasma lipid species associated with rs72613567T >TA in HSD17B13 and rs2642438G $>A$ in MARC1. Volcano plots (A \& D) demonstrating the association (as beta- 
medRxiv preprint doi: https://doi.org/10.1101/2020.06.05.20120956; this version posted June 7,2020 . The copyright holder for this preprint (which was not certified by peer review) is the author/funder, who has granted medRxiv a license to display the preprint in perpetuity. It is made available under a CC-BY-NC 4.0 International license .

regression coefficient) between lipid species and variants, where beta-regression coefficient was calculated by linear regression between genotype (coding $T / T=0, T / T A=1, T A / T A=2$ ) and logarithmically-transformed lipid abundance, adjusted for age and sex. rs72613567T>TA in HSD17B13 was negatively associated with a higher number of double bonds in fatty acids (FA, B). Whilst rs2642438G $>$ A in MARC1 was negatively associated with a higher number of double bonds in phosphatidylinositols (PI). Simple linear regression with 95\% confidence intervals are shown in red. Data from 129 children with biopsy-confirmed NAFLD. CE, cholesterol esters; Cer, ceramides; Chol, cholesterol; DG, diglycerides; LPC, lyso-phosphatidylcholines; PA, phosphatidic acids; PC, phosphatidylcholines; PE, phosphatidylethanolamines; PG, phosphatidylglycerols; PS, phosphatidylserines; SM, sphingomyelin; TG, triglycerides. 
medRxiv preprint doi: https://doi.org/10.1101/2020.06.05.20120956; this version posted June 7, 2020. The copyright holder for this preprint

(which was not certified by peer review) is the author/funder, who has granted medRxiv a license to display the preprint in perpetuity. It is made available under a CC-BY-NC 4.0 International license .

\section{Discussion}

In this study we have provided histological validation of protective MARC1 and HSD17B13 variants in children with NAFLD. Both variants were associated with perturbed phospholipid metabolism and downregulation of fibrotic pathways. Unlike rs72613567T>TA in HSD17B13, hepatic expression of MARC1 is not affected by p.Ala165Thr, suggesting a mechanism of reduced function.

Both rs72613567T>TA in HSD17B13 ${ }^{12}$ and rs2642438G $>A$ in $M A R C 1^{13}$ were originally identified as GWAS-significant risk-reducing loci for liver disease in adults, most recently as risk-reducing variants for all-cause cirrhosis (as well as NAFLD cirrhosis). HSD17B13 has subsequently been validated in multiple cohorts of adults ${ }^{6,14,15,29,57-59}$ though the histological features associated with this variant in MARC1 has not been described in children until now ${ }^{18}$. We therefore selected these two variants to study in children, in addition to the well-established risk-increasing locus rs738409C > G in PNPLA3 and rs58542926C > T in TM6SF2.

The splice variant rs72613567T>TA in HSD17B13 has been consistently associated with lower grade of lobular inflammation, $\mathrm{NASH}$, and stage of fibrosis in adults ${ }^{12}$, though without any difference in severity of histological steatosis ${ }^{14,29}$. In children we observed a strong negative association with grade of peri-portal inflammation with no effect on lobular inflammation. Pediatric $\mathrm{NASH}$ is often characterized by a 'zone 1' predominant distribution of steatosis and inflammation, particularly in younger children ${ }^{23}$. Whilst it has been speculated that the peri-portal inflammation of pediatric NASH 'transitions' to lobular inflammation (and ballooning) of adult NASH, it is challenging to prove. Here, we have observed a genetic variant that has a specific association with peri-portal inflammation in children and with lobular inflammation in adults. We believe this provides further evidence to support the notion that pediatric NASH shares similar genetics to adult NASH, despite having a different histological patterns.

Several groups have previously demonstrated that the splice variant rs72613567T>TA in $H S D 17 B 13$ is associated with reduced expression of the enzyme ${ }^{12,14,29}$, which we have replicated using proteomics. Our pathway analysis also suggested an increase in nonsense-mediated decay, similar to the expression profiling data from Sookoian et $a^{29}$. The function of this enzyme is not exactly clear but has been recently implicated in phospholipid metabolism ${ }^{14}$. Our proteomic and lipidomic data is generally concordant with reduced expression of HSD17B13 causing perturbation of glycerophospholipid metabolism. Though we did not observe precisely the same pattern of altered lipid species as reported by Luukkonen et al. ${ }^{14}$, we used plasma, rather than hepatic tissue, for lipid profiling.

The MARC1 variant discovered by Emdin et al. was associated with lower odds of all-cause cirrhosis, diagnosis of fatty liver, and lower liver fat on $\mathrm{CT}^{13}$. Consistent with this, in children with NAFLD we found a negative association with severity of steatosis, however we did not replicate the finding of lower odds of NAFLD diagnosis. Whilst there was only a negative trend in fibrosis stage our proteomics data gave a signal of downregulation of fibrotic pathways. One explanation for these findings is that this variant primarily reduces hepatic fat and reduced fibrosis (i.e. 
medRxiv preprint doi: https://doi.org/10.1101/2020.06.05.20120956; this version posted June 7, 2020. The copyright holder for this preprint

(which was not certified by peer review) is the author/funder, who has granted medRxiv a license to display the preprint in perpetuity.

It is made available under a CC-BY-NC 4.0 International license .

cirrhosis in adults) is a secondary effect. Data from other variants associated with liver fat does suggest, via a Mendelian randomization method, that degree of steatosis is causally associated with fibrosis stage ${ }^{60}$. However from our, and others' observations, the lack of correlation between steatosis and fibrosis stage with rs72613567T>TA in HSD17B13 suggests that the two histological features can be dissociated. Further mechanistic investigation will be needed to understand the link between these variants, steatosis, and fibrosis.

The precise role of MARC1 in hepatic metabolism is unknown. We found this enzyme to be expressed at similar levels across rs2642438G $>$ A genotypes, even though the variant (p.Ala165Thr) would be predicted to have a destabilizing effect. MARC1 is a molybdenumdependent enzyme that reduces $\mathrm{N}$-oxygenated molecules ${ }^{17,44}$. We found that alanine 165 is highly conserved and threonine-165 may disrupt the alpha-helix and its ability to bind molybdenum. This does appear to affect lipid metabolism as it was associated with reduced abundance of specific plasma phospholipids. Though precisely how this achieved will require further characterization.

Our proteomics showed a consistent trend of increased retinol metabolism associated with HSD17B13 and MARC1 variants, whilst it was reduced with the PNPLA3 variant, as reported previously ${ }^{27}$. Whilst it is possible that a specific common mechanism underlies this, it may also be a secondary observation. Mechanistic work does implicate $P N P L A 3^{61}$ and $H S D 17 B 13$ in retinol metabolism ${ }^{15}$ but it is not known for MARC1. These results could also be accounted for by activation of hepatic stellate cells ${ }^{62}$ in the context of more advanced NAFLD, with an accompanying down-regulation of their retinol metabolism. More generally it is unclear whether disordered retinol metabolism is causal in severity of NAFLD.

The strengths of this study include a comparatively large number of histologically characterised children and use of unbiased lipidomics and proteomics work to give insights into variant function. Also, replication of well-established associations with rs738409C $>G$ in PNPLA3 provides further confidence in our findings. Studying paediatric subjects with NAFLD reduces the risk of interaction with factors attributable to adult multimorbidity or substance toxicity.

In this study we were unable to account for genetic ancestry in analyses due to use of genotyping individual variants. Also, we did not observe an association between rs58542926C $>T$ in TM6SF2 and NAFLD severity, which may have been due to relatively few T-allele carriers. In addition, we may have had reduced power for case-control analyses by use of ultrasound and aminotransferases (rather than more sensitive techniques) for exclusion of steatosis. Therefore, some children with mild steatosis may have been assigned to the control group. Finally, comparatively few children with advanced NAFLD may have meant reduced power to identify further histological associations.

\section{Conclusion}

rs72613567T>TA in HSD17B13 and rs2642438G>A in MARC1 are protective against severity of pediatric NAFLD, suggesting shared genetic effects between adults and children. Proteomic and 
medRxiv preprint doi: https://doi.org/10.1101/2020.06.05.20120956; this version posted June 7,2020 . The copyright holder for this preprint (which was not certified by peer review) is the author/funder, who has granted medRxiv a license to display the preprint in perpetuity. It is made available under a CC-BY-NC 4.0 International license.

lipidomic data implicate the effect of these two variants with perturbation of phospholipid metabolism in hepatic fibrosis.

\section{Acknowledgements}

The authors would like to thank the help of expert pathology review of liver biopsies from Rita De Vito (Rome) and the contribution of the late Valerio Nobili to this project. 
medRxiv preprint doi: https://doi.org/10.1101/2020.06.05.20120956; this version posted June 7, 2020. The copyright holder for this preprint

(which was not certified by peer review) is the author/funder, who has granted medRxiv a license to display the preprint in perpetuity.

It is made available under a CC-BY-NC 4.0 International license .

\section{References}

1. Khera AV, Kathiresan S. Genetics of coronary artery disease: discovery, biology and clinical translation. Nat Rev Genet 2017;18:331-344.

2. Sanyal AJ. Past, present and future perspectives in nonalcoholic fatty liver disease. Nat Rev Gastroenterol Hepatol 2019;16:377-386.

3. Anstee QM, Reeves HL, Kotsiliti E, et al. From NASH to HCC: current concepts and future challenges. Nat Rev Gastroenterol Hepatol 2019;16:411-428.

4. Dufour J-F, Caussy C, Loomba R. Combination for therapy non-alcoholic steatohepatitis: rationale, opportunities and challenges. Gut 2020. Available at: http://dx.doi.org/10.1136/gutjnl-2019-319104.

5. Eslam M, George J. Genetic contributions to NAFLD: leveraging shared genetics to uncover systems biology. Nat Rev Gastroenterol Hepatol 2020;17:40-52.

6. Anstee QM, Darlay R, Cockell S, et al. Genome-wide association study of non-alcoholic fatty liver and steatohepatitis in a histologically-characterised cohort. J Hepatol 2020. Available at: http://dx.doi.org/10.1016/j.jhep.2020.04.003.

7. Romeo S, Kozlitina J, Xing C, et al. Genetic variation in PNPLA3 confers susceptibility to nonalcoholic fatty liver disease. Nat Genet 2008;40:1461-1465.

8. Wang Y, Kory N, BasuRay S, et al. PNPLA3, CGI-58, and Inhibition of Hepatic Triglyceride Hydrolysis in Mice. Hepatology 2019:10.1002/hep.30583.

9. Yang A, Mottillo EP, Mladenovic-Lucas L, et al. Dynamic interactions of ABHD5 with PNPLA3 regulate triacylglycerol metabolism in brown adipocytes. Nature Metabolism 2019;1:560-569.

10. Kozlitina J, Smagris E, Stender S, et al. Exone-wide association study identifies TM6SF2 variant that confers susceptibility to nonalcoholic fatty liver disease. Nat Genet 2014;46:352-356.

11. Pirola CJ, Sookoian S. The dual and opposite role of the TM6SF2-rs58542926 variant in protecting against cardiovascular disease and conferring risk for nonalcoholic fatty liver: A meta-analysis. Hepatology 2015;Epub ahead. Available at:

http://dx.doi.org/10.1002/hep.28142.

12. Abul-Husn NS, Cheng X, Li AH, et al. A Protein-Truncating HSD17B13 Variant and Protection from Chronic Liver Disease. N Engl J Med 2018;378:1096-1106.

13. Emdin CA, Haas M, Khera AV, et al. A missense variant in Mitochondrial Amidoxime Reducing Component 1 gene and protection against liver disease. PLOS Genet 2020:https://doi.org/10.1371/journal.pgen.1008629.

14. Luukkonen PK, Tukiainen T, Juuti A, et al. Hydroxysteroid 17- $\beta$ dehydrogenase 13 variant increases phospholipids and protects against fibrosis in nonalcoholic fatty liver disease. $\mathrm{JCl}$ Insight 2020;5:e132158.

15. Ma Y, Belyaeva OV, Brown PM, et al. 17-Beta Hydroxysteroid Dehydrogenase 13 Is a Hepatic Retinol Dehydrogenase Associated With Histological Features of Nonalcoholic Fatty Liver Disease. Hepatology 2019;69:1504-1519.

16. Klein JM, Busch JD, Pottings $C$, et al. The mitochondrial amidoxime-reducing component (mARC1) is a novel signal-anchored protein of the outer mitochondrial membrane. J Biol Chem 2012;287:42795-42803. 
medRxiv preprint doi: https://doi.org/10.1101/2020.06.05.20120956; this version posted June 7, 2020. The copyright holder for this preprint (which was not certified by peer review) is the author/funder, who has granted medRxiv a license to display the preprint in perpetuity. It is made available under a CC-BY-NC 4.0 International license.

17. Sparacino-Watkins CE, Tejero J, Sun B, et al. Nitrite reductase and nitric-oxide synthase activity of the mitochondrial molybdopterin enzymes mARC1 and mARC2. J Biol Chem 2014;289:10345-10358.

18. Luukkonen PK, Juuti A, Sammalkorpi H, et al. MARC1 variant rs2642438 increases hepatic phosphatidylcholines and decreases severity of non-alcoholic fatty liver disease in humans. J Hepatol 2020. Available at: http://dx.doi.org/10.1016/j.jhep.2020.04.021.

19. Nobili V, Alisi A, Valenti L, et al. NAFLD in children: new genes, new diagnostic modalities and new drugs. Nat Rev Gastroenterol Hepatol 2019;16:517-530.

20. Goyal NP, Schwimmer JB. The Genetics of Pediatric Nonalcoholic Fatty Liver Disease. Clin Liver Dis 2018;22:59-71.

21. Wattacheril J, Lavine JE, Chalasani NP, et al. Genome-Wide Associations Related to Hepatic Histology in Nonalcoholic Fatty Liver Disease in Hispanic Boys. J Pediatr 2017;190:100-107.e2.

22. Anderson EL, Howe LD, Jones HE, et al. The prevalence of non-alcoholic fatty liver disease in children and adolescents: A systematic review and meta-analysis. PLoS One 2015;10. Available at: http://dx.doi.org/10.1371/journal.pone.0140908.

23. Africa JA, Behling CA, Brunt EM, et al. In Children With Nonalcoholic Fatty Liver Disease, Zone 1 Steatosis Is Associated With Advanced Fibrosis. Clin Gastroenterol Hepatol 2018;16:438-446.e1.

24. Nobili V, Alisi A, Newton KP, et al. Comparison of the Phenotype and Approach to Pediatric vs Adult Patients with Nonalcoholic Fatty Liver Disease. Gastroenterology 2016;150:17981810.

25. Mann JP, De Vito R, Mosca A, et al. Portal inflammation is independently associated with fibrosis and metabolic syndrome in pediatric nonalcoholic fatty liver disease. Hepatology 2016;63:745-753.

26. Mann JP, Vreugdenhil A, Socha $P$, et al. European paediatric non-alcoholic fatty liver disease registry (EU-PNAFLD): Design and rationale. Contemp Clin Trials 2018;75:67-71.

27. Hudert CA, Selinski S, Rudolph B, et al. Genetic determinants of steatosis and fibrosis progression in paediatric non-alcoholic fatty liver disease. Liver Int 2019;39:540-556.

28. Vos MB, Abrams SH, Barlow SE, et al. NASPGHAN Clinical Practice Guideline for the Diagnosis and Treatment of Nonalcoholic Fatty Liver Disease in Children:

Recommendations from the Expert Committee on NAFLD (ECON) and the North American Society of Pediatric Gastroenterology, Hepatology and Nu. J Pediatr Gastroenterol Nutr 2017;64:319-334.

29. Pirola CJ, Garaycoechea M, Flichman D, et al. Splice variant rs72613567 prevents worst histologic outcomes in patients with nonalcoholic fatty liver disease. J Lipid Res 2019;60:176-185.

30. Sookoian S, Pirola CJ. Meta-analysis of the influence of I148M variant of patatin-like phospholipase domain containing 3 gene (PNPLA3) on the susceptibility and histological severity of nonalcoholic fatty liver disease. Hepatology 2011;53:1883-1894.

31. Speliotes EK, Yerges-armstrong LM, Wu J, et al. Genome-Wide Association Analysis Identifies Variants Associated with Nonalcoholic Fatty Liver Disease That Have Distinct Effects on Metabolic Traits. PLoS Genet 2011;7:e1001324.

32. Kleiner DE, Brunt EM, Van Natta M, et al. Design and validation of a histological scoring 
medRxiv preprint doi: https://doi.org/10.1101/2020.06.05.20120956; this version posted June 7, 2020. The copyright holder for this preprint

(which was not certified by peer review) is the author/funder, who has granted medRxiv a license to display the preprint in perpetuity.

It is made available under a CC-BY-NC 4.0 International license.

system for nonalcoholic fatty liver disease. Hepatology 2005;41:1313-1321.

33. Brunt EM, Kleiner DE, Wilson $L$ a., et al. Portal chronic inflammation in nonalcoholic fatty liver disease (NAFLD): a histologic marker of advanced NAFLD-clinicopathologic correlation from the Nonalcoholic Steatohepatitis Clinical Research Network. Hepatology 2009;49:809-820.

34. Gielisch I, Meierhofer D. Metabolome and proteome profiling of complex I deficiency induced by rotenone. J Proteome Res 2015;14:224-235.

35. Cox J, Mann M. MaxQuant enables high peptide identification rates, individualized p.p.b.range mass accuracies and proteome-wide protein quantification. Nat Biotechnol 2008;26:1367-1372.

36. Subramanian A, Tamayo P, Mootha VK, et al. Gene set enrichment analysis: a knowledgebased approach for interpreting genome-wide expression profiles. Proc Natl Acad Sci U S A 2005;102:15545-15550.

37. UniProt Consortium. UniProt: a worldwide hub of protein knowledge. Nucleic Acids Res 2019;47:D506-D515.

38. Thusberg J, Olatubosun A, Vihinen M. Performance of mutation pathogenicity prediction methods on missense variants. Hum Mutat 2011;32:358-368.

39. Williams S. Analysis of in silico tools for evaluating missense variants. phenosystems.com. Available at:

http://www.phenosystems.com/www/images/poster/NGRL_Missense_Prediction_Tool_Rep ort.pdf.

40. Capriotti E, Calabrese R, Fariselli P, et al. WS-SNPs\&GO: a web server for predicting the deleterious effect of human protein variants using functional annotation. BMC Genomics 2013;14 Suppl 3:S6.

41. Tang $\mathrm{H}$, Thomas PD. PANTHER-PSEP: predicting disease-causing genetic variants using position-specific evolutionary preservation. Bioinformatics 2016;32:2230-2232.

42. Tavtigian SV, Byrnes GB, Goldgar DE, et al. Classification of rare missense substitutions, using risk surfaces, with genetic- and molecular-epidemiology applications. Hum Mutat 2008;29:1342-1354.

43. Pejaver V, Urresti J, Lugo-Martinez J, et al. MutPred2: inferring the molecular and phenotypic impact of amino acid variants. bioRxiv 2017:134981. Available at: https://www.biorxiv.org/content/10.1101/134981v1 [Accessed May 7, 2020].

44. Kubitza C, Bittner F, Ginsel C, et al. Crystal structure of human mARC1 reveals its exceptional position among eukaryotic molybdenum enzymes. Proceedings of the National Academy of Sciences 2018;115:11958-11963.

45. Capriotti E, Fariselli $P$, Casadio R. I-Mutant2.0: predicting stability changes upon mutation from the protein sequence or structure. Nucleic Acids Res 2005;33:W306-10.

46. Pires DEV, Ascher DB, Blundell TL. DUET: a server for predicting effects of mutations on protein stability using an integrated computational approach. Nucleic Acids Res 2014;42:W314-9.

47. Parthiban V, Gromiha MM, Schomburg D. CUPSAT: prediction of protein stability upon point mutations. Nucleic Acids Res 2006;34:W239-42.

48. Pettersen EF, Goddard TD, Huang CC, et al. UCSF Chimera--a visualization system for exploratory research and analysis. J Comput Chem 2004;25:1605-1612. 
medRxiv preprint doi: https://doi.org/10.1101/2020.06.05.20120956; this version posted June 7, 2020. The copyright holder for this preprint

(which was not certified by peer review) is the author/funder, who has granted medRxiv a license to display the preprint in perpetuity.

It is made available under a CC-BY-NC 4.0 International license .

49. Mann JP, Furse S, Snowden SG, et al. Plasma lipidomics distinguishes NASH and fibrosis from simple fatty liver in children. medRxiv 2020:2020.04.18.20070417.

50. Furse S, Fernandez-Twinn DS, Jenkins B, et al. A high-throughput platform for detailed lipidomic analysis of a range of mouse and human tissues. Anal Bioanal Chem 2020. Available at: http://dx.doi.org/10.1007/s00216-020-02511-0.

51. Harshfield EL, Koulman A, Ziemek D, et al. An Unbiased Lipid Phenotyping Approach To Study the Genetic Determinants of Lipids and Their Association with Coronary Heart Disease Risk Factors. J Proteome Res 2019;18:2397-2410.

52. Koulman A, Prentice $P$, Wong MCY, et al. The development and validation of a fast and robust dried blood spot based lipid profiling method to study infant metabolism. Metabolomics 2014;10:1018-1025.

53. Eiden $M$, Koulman $A$, Hatunic $M$, et al. Mechanistic insights revealed by lipid profiling in monogenic insulin resistance syndromes. Genome Med 2015;7:63.

54. Lu L, Koulman A, Petry CJ, et al. An Unbiased Lipidomics Approach Identifies Early Second Trimester Lipids Predictive of Maternal Glycemic Traits and Gestational Diabetes Mellitus. Diabetes Care 2016;39:2232-2239.

55. Sanders FWB, Acharjee A, Walker C, et al. Hepatic steatosis risk is partly driven by increased de novo lipogenesis following carbohydrate consumption. Genome Biol 2018;19:79.

56. $R$ Core Team. A language and environment for statistical computing. Vienna, Austria: $R$ Foundation for Statistical Computing. 2019.

57. Gellert-Kristensen H, Nordestgaard BG, Tybjaerg-Hansen A, et al. High Risk of Fatty Liver Disease Amplifies the Alanine Transaminase-Lowering Effect of a HSD17B13 Variant. Hepatology 2020;71:56-66.

58. Gellert-Kristensen H, Richardson TG, Davey Smith G, et al. Combined Effect of PNPLA3, TM6SF2, and HSD17B13 Variants on Risk of Cirrhosis and Hepatocellular Carcinoma in the General Population. Hepatology 2020. Available at: http://dx.doi.org/10.1002/hep.31238.

59. Seko Y, Yamaguchi K, Tochiki N, et al. Attenuated effect of PNPLA3 on hepatic fibrosis by HSD17B13 in Japanese patients with non-alcoholic fatty liver disease. Liver Int 2020. Available at: http://dx.doi.org/10.1111/liv.14495.

60. Dongiovanni $P$, Stender S, Pietrelli A, et al. Causal relationship of hepatic fat with liver damage and insulin resistance in nonalcoholic fatty liver. J Intern Med 2018;283:356-370.

61. Pirazzi C, Valenti L, Motta BM, et al. PNPLA3 has retinyl-palmitate lipase activity in human hepatic stellate cells. Hum Mol Genet 2014;23:4077-4085.

62. Tsuchida T, Friedman SL. Mechanisms of hepatic stellate cell activation. Nat Rev Gastroenterol Hepatol 2017;14:397-411. 
medRxiv preprint doi: https://doi.org/10.1101/2020.06.05.20120956; this version posted June 7, 2020. The copyright holder for this preprint (which was not certified by peer review) is the author/funder, who has granted medRxiv a license to display the preprint in perpetuity.

It is made available under a CC-BY-NC 4.0 International license .

\section{Tables}

Table 1.

Clinical and Laboratory Characteristics.

\begin{tabular}{|c|c|c|c|c|}
\hline Variable & Control $(\mathrm{N}=412)$ & NAFLD $(\mathrm{N}=590)$ & $P$ value & $Q$ value \\
\hline Age (years) & $12.3(10.0-14.7)$ & $13.0(11.0-15.4)$ & $7.6 \times 10^{-5}$ & $1.2 \times 10^{-4}$ \\
\hline Male sex, $\mathrm{n}(\%)$ & $181(43.9)$ & $386(66.6)$ & $1.1 \times 10^{-8}$ & $2.9 \times 10^{-8}$ \\
\hline BMI z-score & $3.1(2.6-3.5)$ & $2.4(1.8-3.0)$ & $1.6 \times 10^{-25}$ & $8.5 \times 10^{-25}$ \\
\hline Obesity, n (\%) & 325 (78.9) & $387(66.5)$ & $2.2 \times 10^{-5}$ & $3.9 \times 10^{-5}$ \\
\hline $\operatorname{ALT}(\mathrm{U} / \mathrm{I})$ & $21(17-28)$ & $47(31-78)$ & $1.4 \times 10^{-37}$ & $2.2 \times 10^{-36}$ \\
\hline AST (U/I) & $25(20-30)$ & $38(28-54)$ & $2.0 \times 10^{-29}$ & $1.6 \times 10^{-28}$ \\
\hline GGT (U/l) & $16(13-20)$ & $23(16-36)$ & $1.5 \times 10^{-14}$ & $6.0 \times 10^{-14}$ \\
\hline Cholesterol (mg/dl) & $158(139-178)$ & $160(139-185)$ & 0.531 & 0.571 \\
\hline LDL (mg/dl) & $93(75-112)$ & $97(81-112)$ & 0.488 & 0.571 \\
\hline $\mathrm{HDL}(\mathrm{mg} / \mathrm{dl})$ & $46(39-54)$ & $43(38-50)$ & $3.0 \times 10^{-7}$ & $6.9 \times 10^{-7}$ \\
\hline Triglycerides (mg/dl) & $81(57-108)$ & $98(71-141)$ & $4.0 \times 10^{-6}$ & $8.0 \times 10^{-6}$ \\
\hline HOMA & $2.6(1.7-4.0)$ & $3.7(2.5-5.6)$ & $2.8 \times 10^{-10}$ & $9.0 \times 10^{-10}$ \\
\hline \multicolumn{5}{|c|}{ HSD17B13 genotype, n (\%) } \\
\hline TT / TTA / TATA & $206(55.7) / 143(38.6) / 21(5.7)$ & $394(66.8) / 168(28.5) / 28(4.7)$ & 0.002 & 0.003 \\
\hline \multicolumn{5}{|c|}{ MARC1 genotype, n (\%) } \\
\hline \multicolumn{5}{|c|}{ PNPLA3 genotype, n (\%) } \\
\hline $\mathrm{CC} / \mathrm{CG} / \mathrm{GG}$ & $48(49.5) / 42(43.3) / 7(7.2)$ & $139(35.4) / 172(43.8) / 82(20.9)$ & 0.001 & 0.001 \\
\hline \multicolumn{5}{|c|}{ TMF6SF2 genotype, n (\%) } \\
\hline $\mathrm{CC} / \mathrm{CT} / \mathrm{TT}$ & $84(87.5) / 11(11.5) / 1(1.0)$ & $337(85.8) / 52(13.2) / 4(1.0)$ & 0.535 & 0.571 \\
\hline
\end{tabular}

Table 1. Data represent frequencies (\%) or median (interquartile range) as appropriate. For clinical characteristics, $P$-values were calculated using Mann-Whitney $\mathrm{U}$ test for continuous traits and Chi-square test for categorical traits. For plasma markers, $P$-values were calculated using linear regression with correction for age, sex. For genotypes, $P$-values were calculated using binary logistic regression with correction for age and sex (Wald test). FDR correction ( $Q$ value) for multiple comparisons was calculated using the Benjamini and Hochberg method. BMI, body mass index; ALT, alanine aminotransferase; AST, aspartate aminotransferase; GGT, gamma glutamyl transferase; LDL, low density lipoprotein HDL, high density lipoprotein; HOMA, homeostatic model assessment of insulin resistance 
medRxiv preprint doi: https://doi.org/10.1101/2020.06.05.20120956; this version posted June 7, 2020. The copyright holder for this preprint (which was not certified by peer review) is the author/funder, who has granted medRxiv a license to display the preprint in perpetuity.

It is made available under a CC-BY-NC 4.0 International license .

Table 2.

Histologic Findings.

\begin{tabular}{lccccr}
\hline Grade / Stage & $\begin{array}{l}\text { Steatosis } \\
(\mathrm{N}=394)\end{array}$ & $\begin{array}{l}\text { Portal Inflammation } \\
(\mathrm{N}=386)\end{array}$ & $\begin{array}{l}\text { Lobular Inflammation } \\
(\mathrm{N}=394)\end{array}$ & $\begin{array}{l}\text { Ballooning } \\
(\mathrm{N}=388)\end{array}$ & $\begin{array}{l}\text { Fibrosis } \\
(\mathrm{N}=393)\end{array}$ \\
\hline 0 & - & $117(30.3)$ & $77(19.5)$ & $121(31.2)$ & $90(22.9)$ \\
1 & $90(22.8)$ & $226(58.5)$ & $202(51.3)$ & $161(41.5)$ & $152(38.7)$ \\
2 & $187(47.5)$ & $43(11.1)$ & $115(29.2)$ & $106(27.3)$ & $99(25.2)$ \\
3 & $117(29.7)$ & - & - & - & $5(12.7)$ \\
4 & - & - & - & - & $2(00.5)$ \\
\hline
\end{tabular}

Table 2. Data represent frequencies (\%) of histologic findings in the biopsied study population $(\mathrm{N}=394)$. 